\title{
Ethno-medicinal Plants Used by the People of Nawalparasi District, Central Nepal
}

\author{
S. Bhattarai ${ }^{1}$, R.P. Chaudhary ${ }^{1}$ and R.SL Taylor ${ }^{2}$ \\ ${ }^{1}$ Central Department of Botany, Tribhuvan University, Kirtipur, Kathmandu, Nepal \\ ${ }^{2}$ Community Medicine, Queens University, Kingston, Ontario, Canada
}

Received: 11.02.2009, Accepted: 18.08.2009

\begin{abstract}
Despite new advances in modern medicine, the cultural use of plant in traditional medicine continues from ancient time to this day all over the world. The present research seeks to explore ethnomedicinal plants used by the local people of Nawalparasi district for primary healthcare. Local healers were interviewed regarding the detail uses of plants. When convenient a jungle or forest walk was also conducted, accompanying local healers for plant collection and detailed information gathering. A rich and unique diversity of 94 ethnomedicinal plant species belonging to 49 families under 86 genera were documented. In Nawalparasi, the expense of modern medical treatment combined with the poor economic status of indigenous people and a strong belief in the traditional medicine and traditional medical practitioners are the main reasons for the persistence of the traditional healing system. In addition, we have also documented a lack of continuation and flow of indigenous knowledge from the elders to the younger generation. Youth tend to be attracted by the wave of modernization and do not appreciate the importance of conservation of traditional knowledge. The use of plants in Nawalparasi is an old tradition and the exploration of such unique cultures should be completed thoroughly so that the oral traditions are not lost forever. Immediate conservation and management approaches of valuable medicinal plants with the involvement of local indigenous people of Nawalparasi district will encourage the sustainable conservation of both biological and cultural diversity.
\end{abstract}

Key words: Traditional medicine; Local healers; Heal thcare; Conservation; Nawal parasi

\begin{abstract}
Introduction
Historically plants have been used as a major source of drugs (Newman et al., 2003), and the ancient culture of plant use in traditional medicine continues to this day all over the world. Medicinal plants are gaining popularity because of several perceived advantages, such as fewer side effects, and better patient compliance (Brown et al., 2008). In Nepal, because of the rural nature of the country, modern health services and other organized systems of traditional
\end{abstract}

medicine are not available to the bulk of the population.

Nepal is a multiethnic and multilingual country and has more than 60 different ethnic groups, speaking about 75 languages (Chaudhary, 1998; Shrestha, 1998). Indigenous knowledge about the use of plants as medicine remains the foundation of primary health care in most of the remotes parts of Nepal. This has been attributed to both lack of modern 
government facilities, and the strong respect of the local population in traditional medicines and traditional medicinal practitioners (Bhattarai et al., 2006). Ethnobotanical information remains endemic to certain ethnic groups in Nepal due to lack of communication between the scientific community and indigenous people. Therefore, this present research seeks to explore indigenous knowledge regarding medicinal plants of Nawalparasi.

Nawalparasi ranks 47 out of 75 districts in terms of health institution density and $36^{\text {th }}$ with respect to poverty and deprivation index, socioeconomic and infrastructural development index, and per capita food production (ICIMOD, 2003). The total population of the district is 562,870 (CBS, 2002), and study area consisted predominantly of Tharus and Magars in association with Chhetri and Brahamin.

There have been scattered investigations of the uses of medicinal plants by Tharu and Magar communities in other parts of Nepal (Taylor et al, 1996a, 1996b; Bhattarai, 1998; Mahato, 1998; Chapagain et al., 2004), but few studies (Ghimire, 2000; Gautam, 2003; Parajuli, 2004), have been dedicated to document the knowledge about the plants as medicine in Nawalparasi district. Unique cultural and traditional medicinal practices are still common in most of the Tharu and Magar communities in Nepal. However, the present trend of urbanization and globalization is leading to the loss of traditional knowledge among these indigenous people. In addition, future stresses on medically relevant plant resources remain unpredictable due to limited cultivation of important medicinal plant species (Makunga et al., 2008), and
Nawalparasi district is not exempt from this issues.

\section{Materials and methods}

The present study was undertaken in and around the villages of Nawalparasi district, specifically: Rajahar, Dhusheri, Piprahar, Chhepani, Kuleni, Mukundapur, Pragatinagar, Kuwaswoti, Laukhai, Kushnahar, Taruwa, Badruwa, Pithauli, Amarapuri, Dibyapuri, and Kolhuwa in the Tharu community; and Damahar, Ahalae, Kharsathak, and Baseni in the Magar community. Extensive field trips were conducted during 2004-2008 for the collection of ethnomedicinal information. The information was gathered by direct field observations and interviews with knowledgeable villagers. Consent for the research project was obtained verbally from each villager before they were interviewed. Two interviewing methods were followed. The first was the specimen display method. After collecting plant specimens, these were shown to the locals in order to elicit any information. The same plant specimens were shown to the different knowledgeable people to confirm the accuracy of the results. Upon convenient to the locals, a jungle or forest walk, was conducted, allowing for both plant collection and detailed information gathering (Bhattarai et al., 2006, 2009).

Herbarium specimens were collected and identified with the help of standard literatures (Polunin and Stainton, 1984; Malla et al., 1986; Grierson and Long, 1983-2000), and nomenclature of the identified species follows (Hara et al., 1978, 1982; Hara and Williams, 1979; Press et al., 2000; APG II, 2003). A set of voucher 
herbarium specimens was made for each collection and the voucher numbers are listed in Table 1 . These vouchers have been deposited in the Tribhuvan University Central Herbarium (TUCH), Nepal. The project was approved by the Central Department of Botany Research Committee of Tribhuvan University and University Grant Commission, Nepal.

\section{Resul ts and discussion}

The results of the present study are presented in Table 1 with alphabetical arrangement of plant scientific name followed by family, voucher number, local name and detailed uses. Altogether, 94 plant species belonging to 49 families under 86 genera were reported from the study area. The largest number of plants were noted from the family Fabaceae ( 8 species), followed by Euphorbiaceae (6 species). Family Apocynaceae, Asteraceae and Lamiaceae were represented by five species each. Two families Moraceae and Solanaceae are represented by four species each. Similarly five families, Combretaceae, Lythraceae, Menispermaceae, Myrtaceae and Zingiberaceae were represented by three species each. Five families, Amaranthaceae, Gramineae, Lauraceae, Meliaceae and Piperaceae were represented by two species each. The remaining 32 families were represented by one species each (Table 1).

The most commonly used plant parts were roots ( 31 species), followed by leaves (28 species), bark (21 species), fruits (12 species), whole plant (9 species), seeds (8 species), latex (7 species), flowers (6 species), stem (4 species) and rhizomes (1 species). Medicines are prescribed in different forms including decoction, paste, powder and infusion. In this study, decoctions and paste were found to be used more often in comparison to powder and infusion. Medicines were prepared from both single species and mixtures of plants. Out of 94 species, 25 species were used to cure only one disease while 69 species were used to cure multiple diseases (T able 1).

Roots and leaves may be used more often as medicine because they are vulnerable parts of the plant and at risk for attack by herbivores, insects, fungi, bacteria and nematodes. It benefits the plant to have more biologically active photochemicals in these parts as a defence mechanism. Often these parts of plants contain more active principles, which may explain their selection by local people in traditional medicine.

Table 1: Ethnomedicinal plants used by the people of Nawalparasi District, Nepal. Description: An alphabetical listing of local medicinal plants by species, with family, voucher number and local vernacular name mentioned, as well as a detailed description of preparation and use.

1. Acacia catechu (L.f.) Willd. (Fabaceae), V 1119. 'Khayar' (T).

(a) About $10 \mathrm{~g}$ of pounded bark is taken with a cup of hot water on an empty stomach for diarhoea and dysentery once a day until recovery.

(b) About $10 \mathrm{~g}$ mixture of bark paste of Acacia catechu and Syzygium cumini are dissolved in a cup of hot water with in two spoonfuls of sugar. This mixture is then taken thrice a day for diarrhoea until recovery. 
2. Achyranthes aspera L. (Amaranthaceae), V 2401. 'Naksirka, Uthaanna' (T, M).

(a) About $100 \mathrm{~g}$ of pounded root is boiled in a cup of water and half a cup of decoction is drunk twice a day for diarrhea, dysentery and constipation until recovery. It is used only for children between one to five years.

(b) About $20 \mathrm{~g}$ root, $5 \mathrm{~g}$ fruits of Piper cubeba and $20 \mathrm{~g}$ root of Mimosa pudica are pounded and mixed with a cup of hot water. Five spoonfuls juice is taken twice a day for stomachache until recovery.

(c) About seven leaves are pounded and boiled in a cup of water. Half a cup of decoction is drunk after snake bite which helps to minimize rapid circulation of poison in the blood.

(d) The paste of seven leaves is applied on the snake bite part and tied up in three places above and below the bite by rope. Rope and paste minimize rapid circulation of poison in the body.

(e) About $100 \mathrm{~g}$ of roots, leaves and stem are mixed with $20 \mathrm{~g}$ of Thevetia peruviana bark and pounded. Half a cup of decoction is drunk twice a day for stomachache and constipation until recovery.

3. Acorus calamus L. (Araceae), V 2402. 'Bojho' (N).

(a) About $100 \mathrm{~g}$ of root is boiled in a cup of water and half a cup of decoction is drunk once a day early in the moming for roundworm, and hookworm until recovery. An overdose will lead to vomiting.

(b) Small piece of root is taken in the mouth early in the morning for cough, cold, sore throat, tonsillitis and bronchitis until recovery.
4. Aegle mamelos (L.) Correa (Rutaceae), V 2407. 'Jogchmuda' ( $\mathrm{T}$ ).

(a) Pulp of a single fruit is crushed and half a spoonful of paste is taken thrice a day for 3-7 days to treat diarrhoea until recovery.

(b) About seven leaves are crushed and mixed with half a cup of hot water and taken once a day to cure dysentery and constipation until recovery.

(c) The paste of the fruit pulp is used around ringworm and scabies once a day until recovery.

(d) The ripe fruit pulp is taken for diarrhoea, dysentery, constipation and feeling of higher level of heat inside the body (Symptoms: high body temperature, vomiting, loss of appetite, urine is normally yellow), until recovery.

(e) About half a cup of ripe fruit pulp juice is mixed with a bottle (1 litre) of local alcohol, $200 \mathrm{~g}$ powder of red color (Abhir in Nepali), and taken once a day for diarrhea, dysentery, constipation and feeling of higher level of heat inside the body until recovery.

5. Ageratum conyzoides L. (Asteraceae), V 2404. 'Gandhejhar' (N).

(a) About $100 \mathrm{~g}$ root, is mixed with $100 \mathrm{~g}$ of Pogostemon benghalensis root and boiled in a cup of water. Half a cup of decoction is drunk once a day before going to bed fortyphoid until recovery.

6. Aloe vera (L.) Burm. f. (Liliaceae), V 2408. 'Ghauekumari' (N).

(a) The latex applied to give pain relief for cuts, wounds and burns twice a day until recovery.

7. Alstonia scholaris (L.) R. Br. (Apocynaceae), V 2403. 'Botthaa' (M).

(a) About $500 \mathrm{~g}$ bark, is boiled in 10 litres 
of water and $2 \mathrm{~kg}$ of rice. It is then given once a day to the female pig to induce abortion until abortion is complete.

(b) About $500 \mathrm{~g}$ of bark is mixed with $500 \mathrm{~g}$ of Schima wallichii bark, and $500 \mathrm{~g}$ of Plumeria rubra bark. Boiled this mixture in two $\mathrm{kg}$ of wheat flour and 10 liters of water. All the prepared mixture is then given to the animal twice a day for diarrhoea and dysentery until recovery.

8. Amaranthus spinosus L. (Amaranthaceae), V 2491. 'Setolode' $(\mathrm{N})$.

(a) About $250 \mathrm{~g}$ of pounded root is boiled in two cups of water and half a cup of decoction is drunk twice a day for diuretic until recovery.

9. Artemisia indica Willd. (Asteraceae), V 1092. 'T it epati' (N).

(a) About $5 \mathrm{~g}$ root is pounded with $5 \mathrm{~g}$ bark of Terminalia alata, $2 \mathrm{~g}$ root of Cissampelos pareira, $5 \mathrm{~g}$ bark of Holarrhena pubescens, $2 \mathrm{~g}$ bark of Psidum guajava, $1 \mathrm{~g}$ bulb of Allium sativum, $2 \mathrm{~g}$ seeds of Trachyspermum ammi. One spoonful powder or paste of this mixture is given once a day for gastritis until recovery.

(b) About $5 \mathrm{~g}$ root is mixed with $2 \mathrm{~g}$ root of Cissampelos pareira, $10 \mathrm{~g}$ bark of Holarrhena pubescens, $10 \mathrm{~g}$ bark of Calotropis gigantea and crushed. This is then mixed with $500 \mathrm{~mL}$ of local alcohol. Three spoonfuls of this infusion is then given 2-3 times a day for paralysis until recovery.

(c) Paste of leaves is applied twice day for scabies until recovery.

10. Artocarpus heterophyllus Lam. (Moraceae), V 2410. 'Kathar' (N).

(a) The paste of rind (fruit) is applied on swelling part of scrotum twice a day until recovery.

11. Asparagus racemosus Willd. (Asparagaceae), V 2406. 'Sant apsatauri' (T).

(a) One spoonful of root powder is mixed with two cups of milk and boiled for sometime. About one cup of decoction is drunk once a day as a tonic in lactating a postpartum mother for two weeks. For animals, about half a $\mathrm{kg}$ of root powder is cooked with $5 \mathrm{~kg}$ of rice or wheat and one litre of molasses. It is then given once a day up to two weeks as a tonic in a lactating postpartum animal for twofour weeks.

12. Azadirachta indica A. Juss. (Meliaceae), V 2481. 'Neem' (N).

(a) About 7-10 leaves are boiled in a cup of water and half a cup of decoction is drunk twice a day for anthelmentic, fever and feeling of higher level of heat inside the body until recovery.

(b) About $50 \mathrm{~g}$ bark, is pounded with $50 \mathrm{~g}$ of Cissampelos pareira root, $50 \mathrm{~g}$ of Magnifera indica bark, and $50 \mathrm{~g}$ of Mallotous philippensis bark. This pounded powder mixture is mixed with two cups of water and boiled. Half a cup of decoction is drunk twice a day for gastritis and stomachache until recovery.

13. Bauhinia vahlii Wight \& Arn. (Fabaceae), V 2262. 'Bhorla' (N).

(a) About one spoonful pounded root is given with a cup of hot water for pulmonary tuberculosis twice a day until recovery. During treatment, patients should not eat milk, curd and ghee.

(b) Juice of leaf petiole paste is applied to abrasions once a day until recovery.

14. Boehmeria platyphylla D. Don 
(Urticaceae), V 2417. 'Khasrathi' (M).

(a) Root juice paste is used quickly to stop bleeding in minor cut and wounds.

15. Bombax ceiba L.(Bombacaceae), V 1115. 'Simal' (N).

(a) About $3 \mathrm{~g}$ dry latex, is mixed with $3 \mathrm{~g}$ of dry seed of Mangifera indica and crushed. This mixture is then given 1-2 times a day for diarrhoea until recovery.

16. Calotropis gigantea (L.) Dryand. (Asclepiadaceae), V 2419. 'Aank' (N).

(a) Latex paste is applied on fractured parts of the bone (over the skin of a broken bone), boils and gingivitis twice a day until recovery.

(b) A small twig is smoked and the smoke is blown from the nose to treat sinusitis twice a day until recovery.

(c) About 1-2 spoonful of cow ghee is put over the leaf and warmed in glowing embers of the fire for few seconds. The paste is then applied in testes to treat swelling of testes twice a day until recovery.

17. Cannabis sativa L. (Cannabaceae), V 2630. 'Gajha' (N).

(a) About two spoonfuls of seed are powdered and mixed with one spoonful of seeds of Trachyspermum ammi, and three spoonfuls of black salt in boiling water (about 1 Litre). The decoction is fed twice a day to cattle with diarrhoea until recovery.

(b) About half a spoonful seed is fried in one spoonful of cow ghee and taken once a day for diarrhea, dysentery or constipation until recovery.

(c) The flowers and seeds are mixed with tobacco of cigarette and smoked for cough, cold or constipation by over older members of the community (30 years old and older).

18. Cassia fistula L. (Fabaceae), V 2681. 'Rajbriksha' (N).

(a) About $20 \mathrm{~g}$ seed paste is taken with a cup of hot water as a diuretic, for st omachache, diarrhea or dy sentery twice a day until recovery.

(b) The paste of seeds is applied around the umbilicus (belly button) as a diuretic twice a day until recovery. It is also used for animals for the same diseases mentioned above but the dose is increased.

19. Cassia tora L. (Fabaceae), V 2430. 'Tapra' (N).

(a) About 100 g pounded mixture of leaves and stem is boiled in a cup of water and half a cup of decoction is drunk twice a day for headache until recovery.

20. Centella asiatica (L.) Urb. (Apiaceae), V 2422. 'Dhoat aiyae' (T).

(a) About $100 \mathrm{~g}$ pounded whole plant paste is mixed with $50 \mathrm{~g}$ whole plant paste of Oxalis corniculata, $100 \mathrm{~g}$ of sugarcube and two cups of water. It is then kept overnight. This mixture is filtered and drunk in the moming for fever and feeling of higher level of heat inside the body until recovery.

21. Cinnamomum camphora (L.) J. Presl (Lauraceae), V 2425. 'Kapur' (N).

(a) About 10 leaves are boiled in 4-5 cups of water and vapor is inhaled twice a day for cough and cold until recovery.

(b) About $50 \mathrm{~g}$ leaves paste is mixed with one spoonful of cow ghee and applied on the chest for cough and cold once a day until recovery.

22. Cissampelos pareira L. (Menispermaceae) V 2435. 'Gohman' 
(T).

(a) About $10 \mathrm{~g}$ root paste is given with a cup of hot water twice a day in chronic diseases of children (Runche in Nepali) until recovery.

(b) About 50 g pounded root is boiled with a cup of water and half a cup of decoction is drunk twice a day for headache until recovery.

23. Cissus repens Lam. (Vitaceae), V 2433. 'Rechu' (T).

(a) About 500 g of pounded bark is boiled in four cups of water and decoction is filter. This filter decoction is mixed with $100 \mathrm{~g}$ of sugarcube and 3-5 spoonfuls bark juice of Syzygium cumini. This mixt ure is left for sometime in a cold place to solidify. About half a spoonful of this medicine is taken once a day for cough, cold and bronchitis until recovery.

24. Cleistocalyx operculatus (Roxb.) Merr. and Perry (Myrtaceae), V 2467. 'Kathjamune' (T).

(a) One spoonful bark powder is mixed with tobacco from a cigarette and smoked twice a day for sinusitis until recovery.

(b) About $10-20 \mathrm{~g}$ of pounded bark is boiled in a cup of water and half a cup of decoction is drunk twice a day for sinusitis until recovered.

(c) About $50 \mathrm{~g}$ bark is mixed with seven leaves of Zizyphus mauritiana, two seeds of Terminalia bellerica, two seeds of Terminalia chebula and ground to make powder. Half a spoonful of powder is taken with a cup of hot water twice a day for headache, cough, cold and sinusitis until recovery.

(d) Maize bread is also made using the decoction of the bark and taken once a day for sinusitis.
25. Colebrookea oppositifolia Sm. (Lamiaceae), 'V 2443. 'Bhogate' (T).

(a) About two drops filtered juice of leaf is put inside the eye for eye pain twice a day until recovery.

(b) About $100 \mathrm{~g}$ root powder is mixed with 5 g Datura stramonium seeds powder. One-fourth spoonful powder of this mixt ure is mixed with a cup of hot water and taken to premature ejaculation during sexual intercourse once a day until recovery. Overdose may be harmful to the patients.

26. Costus speciosus (J. Konig) Sm. (Zingiberaceae), V 2702. 'Joghidangha' (M).

(a) About $100 \mathrm{~g}$ of root is boiled with a cup of water and half a cup of decoction is drunk twice a day for headache and diuretic until recovery.

27. Crateva unilocularis Buch.-Ham. (Capparaceae), V 2437. 'Sipligan' (N).

(a) Seed paste is applied ito the forehead for sinusitis once a day until recovery.

(b) About $200 \mathrm{~g}$ of pounded bark is boiled in two cups of water and a cup of filter decoction is drunk once a day for stomachache and sinusitis until recovery.

(c) Root paste is applied on cuts, wounds and boils twice a day until recovery.

28. Curculigo orchioides Gaertn. (Hypoxidaceae), V 2462. 'Musaleri, Dhadhasikharaya' (T, M).

(a) About $200 \mathrm{~g}$ pounded root is boiled in a cup of milk or water and half a cup of decoction is drunk twice a day for headache and lactation in the postpartum mother until recovery.

29. Cuscuta reflexa Roxb. (Convolvulaceae), 'V 2459 'Amarlathi' (T). 
(a) About half a cup of whole plant juice is drunk early in the morning up to thrice a week for hookworm and roundworm until recovery.

(b) About $50 \mathrm{~g}$ of whole plant paste is mixed with $50 \mathrm{~g}$ whole plant paste of Phyllanthus amarus and boiled in two cups of water. Half a cup of decoction is drunk for jaundice twice a day until recovery.

(c) About half a cup of whole plant juice is mixed with $10 \mathrm{~g}$ of Datura stramonium seeds and one cup of molasses. This is then taken 2-3 times a day to prevent rabies infection after mad dog bites, and to treat depression until recovery.

30. Cynodon dactylon (L.) Pers. (Gramineae), V 2493. 'Dubho' (N).

(a) About $50 \mathrm{~g}$ whole plant paste is mixed with two spoonfuls of honey and one spoonful of sugarcube and taken once a day as a tonic to treat vertigo/dizziness until recovery.

(b) About $50 \mathrm{~g}$ of root is pounded by mixing with $50 \mathrm{~g}$ root of Amaranthus spinosus and $50 \mathrm{~g}$ root of Cyperus rotundas. This mixture is then boiled in two cups of water with $100 \mathrm{~g}$ of sugarcube. One cup of decoction is drunk for anthelmentic and stomachache until recovery.

(c) About $100 \mathrm{~g}$ of whole plant paste is mixed with $100 \mathrm{~g}$ of sugarcube, one cup of cow milk and boiled for sometime. This is then taken for defect in vision once a day until recovery.

31. Cynoglossum lanceolatum Forssk. (Boraginaceae), V 2497. 'Khorayana' (M).

(a) About $20 \mathrm{~g}$ roots and flowers are mixed with 10 seeds of Piper cubeba and chewed by the healer, who then blows into the eye of the person suffering from cataracts once a day until recovery

32. Cyperus rotundus L. (Cyperaceae), V 2499. 'Bhada' (T).

(a) About $100 \mathrm{~g}$ root paste is mixed with $100 \mathrm{~g}$ whole plant paste of Polygala arillata, $100 \mathrm{~g}$ root paste of Rauvolfia serpentina, $100 \mathrm{~g}$ root paste of Cissampelos pareira, three leaves of Citrus lemon and one bird [Chatailbird in Gurau (Traditional medicinal practitioners of the study area)]. This is then mixed thoroughly with two bottle of local alcohol and cooked for sometime. Whole mixture is then given once a day for any stomach diseases until recovery.

33. Dalbergia sissoo Roxb. ex DC. (Fabaceae), V 2477. 'Siso' (T).

(a) About $100 \mathrm{~g}$ bark and leaves paste is mixed with $100 \mathrm{~g}$ whole plant paste of Centella asiatica, $100 \mathrm{~g}$ of sugarcube and boiled in two cups of water. Filtered decoction is taken early in the morning for feeling of higher level of heat inside the body or constipation until recovery.

34. Datura stramonium L. (Solanaceae), V 2445. 'Dhatura' (N).

(a) About $5 \mathrm{~g}$ of pounded seeds are taken with a cup of hot water once a day until recovery to treat premature ejaculation in sexual intercourse.

(b) One spoonful juice of leaves is taken once a day for menstrual disorders (heavy menstrual flow) until recovery.

35. Desmodium gangeticum (L.) DC. (Fabaceae), V 2704. 'Gat kosiya' (T).

(a) About $20 \mathrm{~g}$ leaves, stems and flowers are mixed with a cup of water and boiled for sometime. Half a cup of decoction is drunk twice a day for headache until 
recovery.

36. Elephantopus scaber L. (Asteraceae), V 2457. 'Mulapatha' (M).

(a) About $100 \mathrm{~g}$ root paste is drunk with a cup of water for headache and sinusitis twice a day until recovery.

37. Erythrina arborescens Roxb. (Fabaceae), V 2379. 'Pharhed' (T).

(a) Stem bark juice paste is applied to skin abrasions once a day until recovery.

38. Equisetum debile Roxb. ex Vaucher (Equisetaceae), V 2486. 'Sanohadchure' (N).

(a) The paste of the whole plant is applied to treat bone fractures once a day until recovery.

39. Euphorbia royleana Boiss. (Euphorbiaceae), V 1053. 'Sihundisighe' (T).

(a) Leaves are squeezed and half a spoonful juice is taken once a day for cough, cold or constipation until recovery.

(b) About 2-3 leaves are mixed with a cup of curd (yoghurt) and taken twice a day for diarrhea, dysentery or constipation until recovery.

(c) About 1-2 drops of latex paste is applied to wounds inside the ear or to treat ear pain twice a day until recovery.

40. Ficus hispida L. f. (Moraceae), V 2517. 'Dhonghara' (M).

(a) About 2-5 drops of leaves juice is put inside the ear for ear pain or ear wounds twice a day until recovery.

(b) About $100 \mathrm{~g}$ of root paste is boiled with a cup of water and half a cup of decoction is drunk twice a day for diuretic and feeling of higher level of heat inside the body until recovery.

41. Ficus religiosa L. (Moraceae), V 2519. 'Pipal' (N). (a) The paste of bark is applied on cuts and wounds once a day until recovery.

42. Hedychium spicatum Sm. (Zingiberaceae), V 2556. 'Mirkuti' (M).

(a) About $200 \mathrm{~g}$ root is boiled in a cup of water and half a cup of decoction is drunk twice a day for menstrual problems (heavy menstrual flow) until recovery.

43. Hibiscus rosa-sinensis L. (Malvaceae), V 2511. 'Barhamasephool' (N).

(a) Leaf paste is applied around boils to quicken the healing process once a day until recovery. (b) About one-forth of a cup of flower juice is taken twice a day for diuretic until recovery.

44. Holarrhena pubescens (Buch-Ham.) Wall. ex. G. Don. (Apocynaceae), V 1409. 'Dudhakoria' (T).

(a) About $5 \mathrm{~g}$ bark is mixed with $10 \mathrm{~g}$ bark of Terminalia alata and $2 \mathrm{~g}$ root of Cissampelos pareira. It is then pounded and taken once a day on an empty stomach to treat bloody dysentery until recovery.

45. Inula cappa (Buch.-Ham. ex D. Don) DC. (Asteraceae), V 2640. 'Bachhadangha' (M).

(a) About $100 \mathrm{~g}$ root is boiled in a cup of water and half a cup of decoction is drunk twice a day for headache until recovery.

46. Justicia adhatoda L. (Acanthaceae), V 2501. 'Asur' (T).

(a) About 5-7 leaves are boiled in two cups of water, and one-forth of a cup of decoction is drunk for any kinds of fever, cough, cold, asthma, bronchitis and typhoid until recovery.

(b) About 5-10 cups of water is boiled with 5-7 leaves and vapour is inhaled while 
covering the body with warm cloth twice a day for the same diseases mentioned above.

(c) The dried powder of the leaves is mixed with a tobacco of cigarette and then smoked to obtain relief from asthma once a day until recovery.

47. Jatropha curcas L. (Euphorbiaceae), V 1311. 'Sajiwan' (N).

(a) Latex paste is applied on wounds 2-3 times a day until recovery.

48. Kalanchoe spathulata DC. (Crassulaceae), V 2505. 'Ajambari' (N).

(a) About 2-3 drops of the filter leaves juice is put inside the ear for ear pain or ear wounds twice a day until recovery.

49. Lagerstroemia parviflora Roxb. (Lythraceae), V 2509. 'Dhayaro' (N).

(a) About half a cup of flowers juice is taken twice a day for diarrhea and dysentery until recovery.

(b) About half a cup of flower juice is mixed with $50 \mathrm{~g}$ of Panchabakhra (Ayurvedic medicine) and taken once a day for typhoid fever until recovery.

50. Lawsonia inermis L. (Lythraceae), V 2508. 'Mehandi' (N).

(a) About $50 \mathrm{~g}$ leaves paste is mixed with $100 \mathrm{~g}$ fruit bark of Punica granatum and applied on the abrasion part of the skin twice a day until recovery.

(b) About $50 \mathrm{~g}$ seeds are pounded by mixing with $100 \mathrm{~g}$ of Mallotus philippensis bark and boiled in a cup of water for sometime. Half a cup of decoction is mixed with half a cup of honey and taken twice a day for backbone pain or menstrual problems and disorders (pain and irregular flow of blood during the menstrual period) until recovery.

51. Litchi chinensis L. (Sapindaceae), V
1537. 'Litchi' (N).

(a) About $2 \mathrm{~g}$ latex is taken with a cup of hot water twice a day to treat dysentery until recovery.

52. Litsea monopetala (Roxb.) Pers. (Lauraceae), V 2521. 'Kutmero' (N).

(a) Seeds are mixed with confidential mixtures by the 'Gurau' (traditional healer) and used for stomachache twice a day until recovery.

53. Mallotus philippensis (Lam.) Mull. Arg. (Euphorbiaceae), V 2523. 'Rohini' (T).

(a) About 20-50 g bark powder is boiled with a cup of water and mixed in a cup of Aegle marmalos fruit pulp juice. One cup of decoction is drunk early in the morning for diarrhoea and dysentery until recovery.

(b) About $100 \mathrm{~g}$ bark and roots are mixed with $200 \mathrm{~g}$ whole plant paste of Phyllanthus amarus, $100 \mathrm{~g}$ powder of Phyllanthus emblica seeds; 100 g paste of Mangifera indica bark and boiled in two cups of water. Half a cup of decoction is drunk twice a day for asthma, bronchitis or urinary tract infection until recovery.

54. Mangifera indica L. (Anacardiaceae), V 2529. 'Ampa' $(\mathrm{N})$.

(a) About 10 drops juice of bark is mixed with half a pinch of lime powder and immediately given to the children under five years, thrice a day to treat chronic diarrhoea until recovery.

(b) About one-forth of a cup of urine of cow and one-forth root and bark juice of Mangifera indica is taken in separate cups and drunk one by one for gastritis, diarrhoea, dysentery and feeling of higher level of heat inside the body once a day until recovery. 
55. Melia azedarach L. (Meliaceae), V 2007. 'Bakain' (T).

(a) About $10 \mathrm{~g}$ bark paste is mixed in a cup of water and given in empty stomach once a day for three days to treat diarrhoea until recovery.

(b) About two spoonfuls juice of root is mixed with a cup of hot water. Then two spoonful of this infusion is given once a day to treat diarrhoea and cholera until recovery.

(c) About $5 \mathrm{~g}$ bark is ground and mixed with half a cup of cold water and taken once a day for 3-7 days to cure constipation until recovery.

56. Mentha arvensis L. (Lamiaceae), V 2531. 'Patina' $(\mathrm{N})$.

(a) One spoonful of leaf juice is mixed with many confidential mixtures by the 'Gurau' and taken twice a day for cough, cold, dehydration and gastritis until recovery.

57. Mimosa pudica L. (Fabaceae), V 3004. 'Lajjawati' (N).

(a) Half a handful of pounded root is mixed with half a litre of water and boiled for sometime. Then the paste is applied twice a day for cuts and wounds until recovery.

58. Morus serrata Roxb. (Moraceae), V 3000. 'T athimashlari' (T).

(a) About $10 \mathrm{~g}$ pounded root paste is taken with a cup of water twice a day for diarrhoea until recovery. (b) About $100 \mathrm{~g}$ pounded root and bark is boiled in a cup of water and half a cup of decoction is drunk twice a day as an anthelmentic and for typhoid fever until recovery.

59. Nicotiana tabacum L. (Solanaceae), V 2641. 'Surti' (N).

(a) Leaves are heated on glowing embers from the fire and then the leaves are placed on swollen areas of the scrotem and testes once a day until recovery. This helps to reduce swelling of scrotem and testes.

60. Ocimum basilicum L. (Lamiaceae), V 2482. 'Gathiwan' (T).

(a) About half a spoonful of seeds are soaked in three cups of water for 24 hours by adding $50 \mathrm{~g}$ of sugarcube and $10 \mathrm{~g}$ whole plant of Allium wallichii. Two cups of filtered juice is taken once a day for cough, cold and feeling of higher level of heat inside the body until recovery.

61. Ocimum tenuiflorum L. (Lamiaceae), V 2593. 'Tulsi' (N).

(a) About 6-7 leaves are mixed with a cup of curd and taken early in the moming once a day to reduce blood pressure until recovery.

(b) About 2-4 drops of leaf juice is put inside the ear for wounds or ear pain twice a day until recovery.

(c) Two-seven leaves are boiled in two cups of water, $5 \mathrm{~g}$ of Cyperus rotendus root, 5 $\mathrm{g}$ of black salt, $10 \mathrm{~g}$ of Cyanodon dactylon whole plant, $10 \mathrm{~g}$ of Azadirachta indica leaves, $5 \mathrm{~g}$ rhizome of Zingiber officinale, $5 \mathrm{~g}$ of Trachyspermum ammi seeds, $5 \mathrm{~g}$ rhizome of Curcuma angustifolia, and 5 $\mathrm{g}$ seeds of Cuminum cyminum. Then a cup of decoction is drunk once a day for cough, cold, bronchitis, sinusitis, or typhoid fever until recovery.

62. Oxalis corniculata L. (Oxalidaceae), V 2651. 'Chariamilo' (N).

(a) About $100 \mathrm{~g}$ of pounded whole plant is mixed with $50 \mathrm{~g}$ whole plant of Centella asiatica, $50 \mathrm{~g}$ of sugarcube and 1-2 cups 
of water. Filtered juice is drunk once a day for fever and feeling of higher level of heat inside the body until recovery.

63. Pericampylus glaucus (Lam.) Merr. (Menispermaceae), V 2600. 'Khuranijhar' (M).

(a) About $100 \mathrm{~g}$ of root is boiled in a cup of water and half a cup of decoction is drunk twice a day as a diuretic and for dysuria (painful urination) until recovery.

64. Phyllanthus amarus Schumach. \& Thonn. (Euphorbiaceae), V 2563. 'Bhuiamala' (N).

(a) The same use for asthma, bronchitis or urinary tract infection is described in Mallotous philippensis.

65. Phyllanthus emblica L. (Euphorbiaceae), V 2593. 'Amala, Aura' $(\mathrm{N}, \mathrm{T})$.

(a) About $11 \mathrm{~g}$ of fruits powder is mixed with $11 \mathrm{~g}$ of sugarcube, $11 \mathrm{~g}$ of Punica granatum fruit bark juice and a cup of water. Half a cup of juice is drunk thrice a day for heart pain until recovery.

(b) Two seeds of Terminalia chebula are mixed with two seeds of Terminalia bellerica and two-five seeds of Phyllanthus emblica and ground to make fine powder. Half a spoonful powder is drunk with a cup of hot water for constipation, feeling of higher level of heat inside the body, cough, cold or sinusitis until recovery.

(c) About $200 \mathrm{~g}$ of Phyllanthus emblica seeds powder, $100 \mathrm{~g}$ of Mallotous philippensis bark and root paste, $100 \mathrm{~g}$ of Mangifera indica bark powder, is boiled in two cups of water and half a cup of decoction is drunk twice a day for diarrhoea and dysentery until recovery.
66. Piper cubeba L. f. (Piperaceae), V 2558. 'Marich' (N).

(a) One-forth of a spoonful fruit paste is mixed with half a spoonful leaves paste of Azadirachta indica and applied on boils once a day until recovery. After use it may give a burning pain.

(b) About one-forth of a spoonful powder of fruit is mixed with a cup of hot water and drunk once a day for cough, cold, tonsillitis or bronchitis until recovery.

(c) About 1-2 spoonfuls of fruit powder is mixed with three cups of oil and boiled for sometime. Then the heads of a live snake, scorpion and lizard are dipped one by one in this boiled oil for sometime. Then the decoction is boiled for sometime and the paste is applied on any kinds of wounds (those wounds which are not cured by any other kind of medicine) once a day until recovery. This treatment can be done only by the Gurau (Traditional medicinal practitioners in Tharu Community).

67. Piper longum L. (Piperaceae), V 2536. 'Jadhi' (M).

(a) About $100 \mathrm{~g}$ root paste is drunk with a cup of milk 2-3 times a day for menstrual disorders (heavy menstrual flow) until recovery.

68. Plumbago zeylanica L. (Plumbaginaceae), V 2539. 'Kalamnath' (T).

(a) The milky juice paste is applied in blister, wart and ringworm twice a day until recovery.

(b) Half a spoonful of whole plant paste is taken twice a day with a cup of milk for diarrhea, dysentery, fever or stomachache until recovery.

69. Plumeria rubra L. (Apocynaceae), V 
2586. 'Galaini' (N).

(a) About $50 \mathrm{~g}$ of stem bark is pounded with $50 \mathrm{~g}$ of Thevetia peruviana flowers and $10 \mathrm{~g}$ root of Achyranthus aspera. It is then boiled in two cups of water and one cup of decoction is drunk twice a day for stomachache until recovery.

(b) About $100 \mathrm{~g}$ stem bark is mixed with $100 \mathrm{~g}$ of jaggery and approximately 100 $\mathrm{g}$ of dead dragonflies and cooked. This is then taken twice a day to try to prevent rabies infection after someone is bitten by a mad dog. It is taken until the patient recovers, which the healers stated does happen.

70. Pogostemon benghalensis (Burm.f.) Kuntze (Lamiaceae), 'V 2571. 'Bhati' (T).

(a) About $50-100 \mathrm{~g}$ of whole plant paste is boiled in a cup of water and half a cup of decoction is drunk twice a day for fever, cough, cold or typhoid fever until recovery.

(b) About 10-20 g root powder is mixed with 10-20 g paste of whole plant of Oxalis corniculata, 10-20 g of whole plant paste of Centella asiatica and boiled in a cup of water. Half a cup of decoction is drunk twice a day for the same diseases mentioned above until recovery.

71. Polygala arillata Buch.-Ham. ex D. Don (Polygalaceae), V 2580. 'Thanak' (T).

(a) About $100 \mathrm{~g}$ whole plant paste is mixed with one bottle of local alcohol, $100 \mathrm{~g}$ of Inula cappa flowers, $100 \mathrm{~g}$ of Cissampelos pariera root and $100 \mathrm{~g}$ root of Tinospora sinensis. Then about 200 $\mathrm{mL}$ juice is drunk 2-3 times a day for tonsillitis, stomachache, gastritis, cough, cold or "wounds inside the stomach" (likely stomach ulcers) recovery.

72. Prunus persica (L.) Batsch (Rosaceae), V 2520. 'Aru' (N).

(a) About half a cup of leaves juice paste is applied on wounds to kill 'small wound worms' once a day until recovery.

73. Psidium guajava L. (Myrtaceae), V 4004. 'Runi' (T).

(a) About $10 \mathrm{~g}$ bark is mixed with half a spoonful of Trachyspermum ammi seeds, half a spoonful leaves paste of Syzygium cumini, and a paste of seven leaves of Aegle mamelos. This mixture is then taken for diarrhoea and dysentery twice a day until recovery.

(b) Fruit is fried on red embers of the fire and one fruit is taken twice a day for constipation, fever, cough or cold until recovery.

(c) About two spoonfuls bark juice is mixed with confidential mixtures by 'Gurau' and used an anthelmentic twice a day until recovery.

74. Punica granatum L. (Punicaceae), V 2566. 'Darim' (N).

(a) About $20 \mathrm{~g}$ fruit bark is pounded with 20 g stem bark of Syzygium cumini and two spoonfuls juice is taken 2-3 times a day to treat diarrhoea until recovery.

(b) see Lawsonia inemis for the description of treatment of skin abrasions.

(c) About half a cup of decoction is made with a cup of water and $10 \mathrm{~g}$ fruit bark. It is then drunk twice a day for diarrhea and dysentery until recovery.

75. Rauvolfia serpentina (L.) Benth. ex Kurz (Apocynaceae), 'V 2592. 'Dhaldhaliya, Dharmarua' (T).

(a) The root paste is applied on cuts, wounds or boils twice a day until recovery. 
(b) About $10 \mathrm{~g}$ root paste is mixed with a cup of water and drunk early in the morning for fever, stomachache, menstrual disorders (heavy menstrual periods, pain during menstrual periods), until recovery. This can also be used for animals by mixing with foods for the same diseases mentioned above but the dose can be increased.

(c) About $10 \mathrm{~g}$ of root juice is drunk for snake bite to minimize the rapid circulation of poison in the blood. Over dose may kill the patient.

76. Reinwardtia indica Dumort. (Linaceae), V 2701. 'Dauthi Phool' (M).

(a) About $200 \mathrm{~g}$ of root paste is mixed with a cup of water and boiled. Half a cup of decoction is drunk to increase lactation in postpartum mothers twice a day until recovery.

77. Ricinus communis L. (Euphorbiaceae), V 2581. 'Reyar' (T).

(a) Seed oil is applied on skin abrasions twice a day until recovery. (b) Hot ash is put over 4-5 leaves and the leaves are put over the fractured part of the bone to relieve pain twice a day until recovery.

78. Schima wallichii (DC.) Korth. (Theaceae), V 2570. 'Chilaunee' (N).

(a) About $100 \mathrm{~g}$ pounded bark is boiled in a cup of water and the paste is applied on wounds twice a day until recovery.

(b) The mode of use for diarrhea and dysentery is same as described in Alstonia scholaris.

79. Shorea robusta Gaertn. (Dipterocarpaceae), V 2540. 'Jennah' (T).

(a) About 10-20 g of latex is mixed with a cup of curd and taken twice a day for diarrhea and bloody dysentery until recovery

80. Solanum anguivi Lam. (Solanaceae), V 2692. 'Sanobihi' (N).

(a) Paste of fruit is applied on forehead to treat headache twice a day until recovery.

81. Solanum nignum L. (Solanaceae), V 2606. 'Kanthakari' (N).

(a) About 5-10 fruits paste is taken with a cup of boiled water for headache once a day until recovery.

82. Spilanthes calva DC. (Asteraceae), V 2602. 'Kawakchini' (T).

(a) About 2-5 flowers are taken with a cup of hot water for cough, cold or gingivitis twice a day until recovery.

83. Syzyzium cumini (L.) Skeels (Myrtaceae), V 1117. 'Jamuna' (T).

(a) About $20 \mathrm{~g}$ bark, is pounded with $20 \mathrm{~g}$ root of Zizyphus mauritiana, $20 \mathrm{~g}$ fruit bark of Punica granatum. Then two spoonfuls juice is taken 2-3 times a day to treat diarrhoea until recovery.

84. Terminalia alata Heyne ex Roth (Combretaceae), V 1116. 'Saj, Asna' (N, $\mathrm{T})$.

(a) About $10 \mathrm{~g}$ powdered bark is mixed in half a cup of water and taken twice a day for diarrhoea until recovery.

(b) About $10 \mathrm{~g}$ bark and $2 \mathrm{~g}$ root of Cissampelos pareira is powder and given once a day to cure stomachache until recovery.

85. Terminalia bellirica (Gaertn.) Roxb. (Combretaceae), V 2604. 'Asida' (N, T).

(a) The use for cough, cold, gastritis, stomachache or constipation is same as described in Phyllanthus emblica.

(b) One fruit is fried on a glowing ember and then eaten for cough and cold twice a day until recovery. 
86. Terminalia chebula Retz. (Combretaceae), V 2607. 'Harro' (N).

(a) One fruit is fried on a glowing ember and then eaten for cough and cold twice a day until recovery.

87. Thevetia peruviana (Pers.) K. Schum. (Apocynaceae), V 2560. 'Karbir' (N).

(a) About 2-5 drops of hot leaves juice put inside the ear for ear pain or wounds until recovery.

88. Thysanolaena maxima (Roxb.) Kuntze (Gramineae), V 2609. 'Bashadi' (T).

(a) The root paste is applied on boils twice a day until recovery to quicken the healing process.

89. Tinospora sinensis (Lour.) Merr. (Menispermaceae), V 2711. 'Gurjo' (N).

(a) About $500 \mathrm{~g}$ root is pounded and mixed with two cups of water and boiled for sometime. Half a cup of decoction is drunk twice a day for diarrhoea, dysentery, stomachache or diuretic until recovery.

90. Vitex negundo L. (Verbenaceae), V 2611. 'Simali' (N).

(a) About five drops of filter juice of leaves is put inside the ear for ear pain or wounds twice a day until recovery.

91. Woodfordia fruticosa (L.) Kurz (Lythraceae), V 2617. 'Ghayaro' (T).

(a) About five spoonfuls of flowers and bark juice is taken twice a day for stomachache, diarrhoea, dysentery or typhoid fever until recovery.

92. Xeromphis spinosa (Thunb.) Keay (Rubiaceae), V 1688. 'Mainkada' (N).

(a) About $200 \mathrm{~g}$ bark powder is boiled in two cups of water and half a cup of decoction is drunk twice a day for gastritis or stomachache until recovery.

(b) About $100 \mathrm{~g}$ of bark powder is mixed with two cups of water, $50 \mathrm{~g}$ bark paste of Mallotous philippensis, Mangifera indica, Cissampelos pariera, Cleistocalyx operculatus each and $50 \mathrm{~g}$ of sugarcube. Half a cup of decoction is drunk once a day for gastritis or stomachache until recovery.

93. Zingiber officinale (Willd.) (Zingiberaceae), 'Adrakh' (T). V 1688.

(a) About 2-4 leaflets are crushed and juice is given twice a day for diarrhoea until recovery. (b) About 1-2 drops of filtered juice of the rhizome is put inside the nose for sinusitis until recovery.

94. Zizyphus mauritiana Lam. (Rhamnaceae), V 2639. 'Bayar' (N).

(a) About one cup of raw milk (not boiled) of a black goat is mixed with paste of two ripe fruits and taken once a day to treat measles until recovery.

$\mathrm{N}=$ Nepali, $\mathrm{T}=$ Tharu, $\mathrm{M}=$ Magar, $\mathrm{V}=$ Voucher, $g=$ Gram.

Plant species were generally prepared as medicine using hot and cold water as the solvent but occasionally remedies were prepared with milk, sugarcube, alcohol, curd, honey, ghee, sugarcane juice, molasses, jaggery, oil or cow urine. Local people use more water in the preparation of medicine. This may be explained because water is easily accessible, or because of a decreased availability of other infusion materials. Water may also be the most effective solvent for dissolving the biologically active chemicals present in the plant. However, occasionally alcohol, milk, oil or sugarcane juice are used as solvents. They may be chosen because certain active principles are more readily dissolved in these liquids. In addition honey, sugarcube, 
molasses, jaggery, curd and ghee are also added to some medicines. These additives may help with extraction of the active components, make the active chemicals more bioavailable, or help synergistic interactions.

Many plant species of Nawalparasi district are used for medicine, but several are very popular and known throughout Nepal. Most of these popular species including Achyranthes aspera, Mallotus philippensis, Piper cubeba, and Rauvolfia serpentina, are used to treat a broad range of ailments, while several species, including Zingiber officinale, and Thysanolaena maxima, are found to treat only one ailment. Among these plants, Rauvolfia serpentina is banned for export outside the country of Nepal without processing because it listed in Endangered and CITES-Appendix II of the Government of Nepal protected plants list (GON, 2006).

In Nawalparasi, the root of Rauvolfia serpentina is used to treat broad range of ailments including cuts, wounds, boils, fever, stomachache, snake bites, and menstrual disorders. Similarly use of Piper cubeba, at the local level is very interesting, and would benefit from thorough investigation. The fruit is mixed with Azadirachta indica leaves and oil to make paste to quicken the healing of boils and is also used to treat cough, cold, tonsillitis and bronchitis. In addition the heads of a live snake, scorpion and lizard are dipped in boiling oil containing Piper cubeba paste (Tab. 1). This paste is then used to treat wounds that would not heal with other treatments.

The healthcare system in remote villages of Damahar, Ahalae, Kharsathak, and
Baseni is basic, and traditional medicines are the primary source of healthcare. Although a few allopathic medicines are available in the government health posts, but because of traditional and cultural customs and beliefs many people rely on local traditional healers for their healthcare. Local healers have a great knowledge about the use of medicinal plants and the villagers rely heavily on them, and are not without health care.

The present survey shows that indigenous people maintain their health through the use of various plants as medicine and have developed a close relationship to the plant world. In Nawalparasi, expensive allopathic medical treatment, low economic status of the indigenous people for modern medicine and a strong belief on the traditional medicine and traditional medical practitioners are the main causes of the persistence of the traditional healing system. However, we have also documented a lack of continuation and flow of indigenous knowledge from the elder to the younger generation. Now a days, young people are attracted by the wave of modernization and do not appreciate the value of conservation of traditional knowledge. The use of plants in Nawalparasi is an old tradition and the exploration of this culture should be completed thoroughly in case the oral traditions are lost forever. Immediate conservation and management approaches of valuable medicinal plants with the involvement of local indigenous people of Nawalparasi district will encourage the sustainable conservation of both biological and cultural diversity. 
S. Bhattarai, R.P. Chaudhary and R. SL T aylor / Our Nature (2009) 7: 82-99

\section{Acknowle dgemen ts}

The first author is thankful to the Volkswagen Foundation, Germany and University Grant Commission, Nepal for the financial support for the field work. We are grateful to the local people of Nawalparasi for providing their valuable ethnobotanical information and cooperation.

\section{References}

Angiosperm Phylogeny Group II 2003. An update of the Angiosperm Phylogeny Group classification for the orders and families of flowering plants: APG II. Botanical Journal of the Linnean Society 141 : 399436.

Bhattarai, N.K. 1998. Traditional Medicine, Medicinal plants and biodiversity Conservation in the global and Nepalese contexts. Plant Research 1(1): 22-31.

Bhattarai, S., R.P. Chaudhary and R.S.L. Taylor 2006. Ethnomedicinal plants used by the People of Manang district, central Nepal. Journal of Ethnobiology and Ethnomedicine, 2: 41.

Bhattarai, S., R.P. Chaudhary and R.S.L. Taylor 2009. Wild edible plants used by the people of Manang District, Central Nepal. Ecology of Food and Nutrition 47: 1-20.

Brown, L., O. Heyneke, D. Brown, J.P.H. Wylvan and J.H. Hamman 2008. Impact of traditional medicinal plant extracts on antiretrovial drug absomtion. Journal of Ethnopharmacology 119:588-592.

CBS 2002. Population of Nepal: Village Development Committees/Municipalities population census 2001. His Majesty's Government of Nepal. National Planning Commission Secretarial, Central Bereau of Statistics, United Nations Population Fund.

Chapagain, D.J., S.D. Joshi and S.R. Jnawali 2004. Use of medicinal plants by Tharu community in the southwestem buffer zone of Royal Bardia National Park. Scientific world 2(2): 50-62.

Chaudhary, R.P. 1998. Biodiversity in Nepal: Status and Conservation. S. Devi, Saharanpur (UP.), India and Tecpress Books Bangkok, Thailand.

Gautam, S. 2003. Medicinal plants used to treat respiratory complaints in Nawalparasi district (Central Nepal), and their antibacterial activity. Central Department of Botany, Tribhuvan
University, Kirtipur, Kathmandu, Nepal. (M.Sc. Dissertation)

Ghimire, K. 2000. Ethno-medico-botany of Tharu tribe of Nawalparasi district. In: Proceeding of the third regional workshop on community based NTFP management (Ed. S.M. Amatya). Institute of Forestry, Pokhara, Nepal.

GON 2006. Plants of Nepal: Fact Sheet. Government of Nepal, Ministry of Forest and Soil Conservation, Department of Plant Resources, Thapathali, Kathmandu, Nepal.

Grierson, A.J.C. and D.G. Long 1983-2000. Flora of Bhutan. Vol. I \& II. Part I-III. Royal Botanic Garden, Edinburgh and Royal Govemment of Bhutan.

Hara, H., A.O. Charter and L.H.J. Williams 1982.An Enumeration of the Flowering plants of Nepal. Volume III. British Museum of Natural History, London.

Hara, H., and L.H.J. Williams 1979. An Enumeration of the Flowering Plants of Nepal. Volume II. British Museum of Natural History, London.

Hara, H., W.T. Stearn and L.H.J. Williams 1978. An Enumeration of the Flowering Plants of Nepal. Volume I. British Museum of Natural History, London.

ICIMOD 2003. Districts of Nepal Indicators of Development. Central Bureau of Statistics (CBS), Nepal, International Centre for Integrated Mountain Development (ICIMOD/MENRIS), SNV-Nepal.

Mahato, R.B. 1998. Notes on some plants of Ethnobotanical importance from Palpa district. Tribhuvan University Journal 21(1): 71-76.

Makunga N.P., L.E. Philander and M. Smith 2008. Current perspectives on an emerging formal natural products sector in South Africa. Journal of Ethnopharmacology 119: 365-375.

Malla, S.B., S.B. Rajbhandari, T.B. Shrestha, P.M. Adhikari, S.R. Adhikari and P.R. Shakya 1986. Flora of Kathmandu Valley. Bulletin of Department of Medicinal Plants of Nepal. His Majesty's Government, Ministry of Forest and Soil Conservation, Department of Medicinal Plants, Thapathali, Kathmandu, Nepal, HMG Press, Singha Durbar, Kathmandu.

Newman, D.J., G.M. Cragg and K.M. Snader 2003. Natural products as a source of new drugs over the period 1981-2002. Journal of Natural Products 66: 1022-1037. 
S. Bhattarai, R.P. Chaudhary and R. SL T aylor / Our Nature (2009) 7: 82-99

Parajuli, B. 2004. Ethnobotany and antimicrobial activities of medicinal plants used in diarrhoea and dysentry in Nawalparasi district, Nepal. Central Department of Botany, Tribhuvan University, Kirtipur, Kathmandu, Nepal. (M.Sc. Dissertation)

Polunin, O. and A. Stainton 1984. Flowers of the Himalaya. Oxford University Press, New Delhi, India. $283 \mathrm{p}$.

Press, J.R., K.K. Shrestha and DA. Sutton 2000. Annotated Checklist of the flowering Plants of Nepal. Natural History Museum, London and Central Department of Botany, Tribhuvan University, Kathmandu.

Shrestha, K.K. 1998. Ethnobotanical inventory and plant taxonomy: Basic approaches for ethnobotanical research. In Ethnobotany for Conservation and Community Development. (Eds. K.K., Shrestha, P.K., Jha, P., Shengji, A., Rastogi, S., Rajbhandari and M. Joshi), Ethnobotanical Society of Nepal, Kathmandu, Nepal.Pp. 58-65.

Taylor, R. SL, F. Edel, N.P. Manandhar and G.H.N. Towers 1996a. Antimicrobial activities of southern Nepalese medicinal plants. Journal of Ethnopharmacology 50:97-102.

Taylor, R. SL, NP. Manandhar, J.B. Hudson and G.H.N. Towers 1996b. Antiviral activities of medicinal plants of southem Nepal. Journal of Ethnopharmacology 53:97-104. 